\title{
USING A SOIL QUALITY INDEX TO ASSESS THE EFFECTS OF APPLYING SWINE MANURE COMPOST ON SOIL QUALITY UNDER A CROP ROTATION SYSTEM IN TAIWAN
}

\author{
Chia-Hsing Lee', Mao-Yi Wu', Victor B. Asio ${ }^{2}$, and Zuens-Sang Chen ${ }^{1}$
}

Soil quality indices (SQI) have been proposed in recent years as tools for assessing soil management practice effects on soil quality. In this paper, we report the result of our 4-year study on the use of a SQI to assess the effects of applying swine manure compost on soil quality. Cabbage (Brassica camperstris L.) and maize (Zea mays L.) $_{\text {.) }}$ were grown in rotation in plots applied with low, medium, and high rates of swine manure compost while the control received only chemical fertilizers. Selected soil physical, chemical, and biological properties (bulk density, aggregate stability, organic carbon content, soil $\mathrm{pH}$, available $\mathrm{N}, \mathrm{P}$, and $\mathrm{K}$, extractable $\mathrm{Cu}$ and $\mathrm{Zn}$, and microbial biomass), all of which were identified as possible soil quality indicators, were monitored at regular intervals. Tissues of harvested crops were analyzed for $\mathrm{Cu}$ and $\mathrm{Zn}$ concentrations because they were anticipated to increase due to the high amounts of the metals in the manure compost. A SQI model was derived based on Mausbach and Seybold's research and on our soil database and research experience in Taiwan. Data from our manure application experiment were used to calculate the SQI values for the different treatments. Results revealed that application of swine manure compost improved the soil quality of surface soil as indicated by increased values of soil quality indicators, SQI, and yields of the crops. In addition, $\mathrm{Cu}$ and $\mathrm{Zn}$ levels in the soil and in the crop tissues did not increase to harmful levels. Thus, it seems that the SQI was an effective tool to assess the effects of swine manure compost application on soil quality. The soil indicators we found effective included the monitored properties except for bulk density. All of these soil properties were significantly increased by manure compost application. Long-term application of 40-60 tons ha ${ }^{-1}$ year $^{-1}$ of manure compost may improve the soil quality and increase the yield of the crops without polluting the soil and crops with $\mathrm{Cu}$ and $\mathrm{Zn}$. (Soil Science 2006;171:210-222)

Key words: Soil quality, swine manure compost, cabbage (Brassica camperstris L.), maize (Zea mays L.), soil quality indicators, soil quality index model, soil properties.

$\mathbf{S}$ OIL quality is defined as the capacity of a soil to function, within ecosystem and land-use boundaries, to sustain biological activity, maintain environmental quality, and promote plant, animal, and human health (Doran and Parkin,

\footnotetext{
'Department of Agricultural Chemistry, National Taiwan University, Taipei 106-17, Taiwan. Dr. Chen is corresponding author. E-mail: soilchen@ntu.edu.tw

2Institute of Tropical Ecology, Leyte State University, Baybay, Leyte 6521-A, Philippines.

Received June 25, 2005; accepted Oct. 17, 2005.

DOI: $10.1097 / 01 . s s .0000199700 .78956 .8 \mathrm{c}$
}

1994; Doran et al., 1996). It reflects the biological, chemical, and physical properties and processes and their interactions within each soil resource (Karlen et al., 2001). It also relates to the dynamic nature of soil as influenced by human use and management (Mausbach and Seybold, 1998). Carter et al. (1997) stressed that the concept of soil quality is relative to a specific soil function or use. The soil functions include serving as a medium for plant growth (biomass production); an environmental filter, buffer, and transformer; a habitat of flora and fauna; and a 
living space for humans (Brady and Weil, 2002; Schlichting, 1986; Schroeder and Blum, 1992).

As soil quality is difficult to quantify directly (e.g., Sojka and Upchurch, 1999), a minimum data set of soil properties or indicators has been proposed as a means to infer a soil's ability to perform these basic functions (Mausbach and Seybold, 1998). To perform as good indicators, the selected soil properties should be sensitive, easy to measure, verifiable, and well related to land management and the effect of environmental transformation (Carter et al., 1997; Seybold et al., 2001).

Three general comparative approaches for assessing soil quality are proposed in the USDA soil quality test kit guide, namely, (1) comparing different management systems for differences in soil quality, (2) comparing the same site over time and determining a trend, and (3) comparing the problem areas with nonproblem areas within a field. The second approach involves assessing changes in the properties of surface soil over time to identify the trends (Seybold et al., 2001). Monitoring trends requires establishing baseline values for the various soil properties and measuring changes of those properties over time. If the change of a soil quality indicator is positive (more means better quality), then the soil can be regarded as improving or aggrading in soil quality with respect to that soil property. Conversely, if the trend line is negative for that indicator, then soil quality is degrading. A flat trend would indicate a sustaining system.

Until now there has been no reliable and practical tool or method to assess soil quality although several investigators have proposed conceptual frameworks and models to evaluate soil quality changes under different soil management systems (e.g., Harris et al., 1996; Karlen and Stoot, 1994; Karlen et al., 1997; MacDonald et al., 1995; Mausbach and Seybold, 1998). Karlen and Stott (1994) suggested that the measurements of soil quality indicators can be transferred to simple values (from 0 to 1 ) through standard scoring functions (SSF). These standardized values can be easily interpreted to reflect the alteration of soil properties under specific soil-plant systems through time. Moreover, the values of a minimum data set of indicators can be combined into a soil quality index (SQI) through a flexible SQI model. Karlen et al. (2001) stressed that there are no magic scores or perfect ratings as both inherent and dynamic soil properties and processes are involved in the calculation of a SQI. They added that for all SQI calculations, it is important to establish criteria or conditions that can be used to guide the evaluations, such as establishing ranges for indicator values that are appropriate for the specific soil being evaluated, determining how data collected for each indicator should be scored or interpreted, and determining the relative importance or weight that should be given to each indicator. Because the SQI concept is simple, and it views soil quality variations in a holistic manner, it may be useful to assess the changes in soil quality under various soil management systems and environmental conditions.

Soil quality varies with soil management. Manure application is widely practiced as a soil fertility management strategy in many tropical and sub-tropical countries. In Taiwan, the use of swine manure compost has become popular among farmers and is being encouraged by the government to recycle, and minimize pollution effects of, the more than 10 million tons of swine manure that is produced by the swine industry annually (Chen and Yang, 1996). However, the practice of adding copper to livestock feed to enhance the swine's growth has environmental quality implications. High $\mathrm{Cu}$ concentration in the feeds results in the reduction of $\mathrm{Zn}$ absorption, thus the supplemental addition of $\mathrm{Zn}$ into the feed is necessary to maintain the swine's health. Consequently, swine manure generally contains high concentrations of $\mathrm{Cu}$ and $\mathrm{Zn}$ (Chen and Yang, 1996). Thus, the use of swine manure compost as fertilizer can result in $\mathrm{Cu}$ and $\mathrm{Zn}$ accumulation in the soil. It may also increase the risk of contaminating the food chain as a result of the accumulation of the trace elements in crops (L'Herroux et al., 1997; Miller et al., 1986; Mullins et al., 1982). This implies that while manure application generally improves soil quality, it may also reduce some soil functions or the quality of agricultural soils.

The objectives of this 4-year study were (1) to evaluate some soil properties as indicators of soil quality, and (2) to use a SQI to assess the effects of applying swine manure compost on soil quality under a crop rotation system.

\section{MATERIALS AND METHODS}

\section{Study Site}

The study was carried out at the experimental station of the National Taiwan University, Taipei, Taiwan, established for more than 90 years for the study of the cultivation of various 
vegetables and rice. The soil is Kugkuantzu silt loam, classified as a loamy, mixed, hyperthermic, Aquic Hapludept based on soil taxonomy. The study site is in sub-tropical zone mixed with continental and oceanic climate. The weather is strongly affected by the northeast monsoon in winter. Annual rainfall during the experiment from 1997 to 2001 was 2595, 4404, 1958, and $2744 \mathrm{~mm}$, respectively. The average temperature of each month during study period ranged from 15.3 to $30.1{ }^{\circ} \mathrm{C}$. In Taiwan, most of croplands are cultivated for two rice crops annually or even more frequently. The weather is dry season from November to April and the wet season is from May to October. The basic soil properties of the study site are shown in Table 1.

\section{Application Rate of Manure Compost}

Commercial swine manure compost was used with the following analysis of major nutrient elements: $\mathrm{N}(1.64 \%), \mathrm{P}(0.31 \%)$, and $\mathrm{K}(1.16 \%)$. The $\mathrm{pH}$ of the compost was 7.2 and electric conductivity (EC) was $7.1 \mathrm{dS} \mathrm{m}^{-1}(1: 5 \mathrm{w} / \mathrm{w}$; compost to distilled water ratio). The soil moisture was $18-32 \%$ in the field conditions. The total $\mathrm{Cu}$ and $\mathrm{Zn}$ concentrations of studied compost of 96 and $133 \mathrm{mg} \mathrm{kg}^{-1}$ were detected. Four treatments or levels of manure compost application were used: control (no compost application), low (first application: 30 tons $\mathrm{ha}^{-1}$; second application: 20 tons $\mathrm{ha}^{-1}$ ); medium (first application: 60 tons ha ${ }^{-1}$; second application: 40 tons $\mathrm{ha}^{-1}$ ); and high (first application: 120 tons $\mathrm{ha}^{-1}$; second application: 60 tons $\mathrm{ha}^{-1}$ ). The first application of the compost was applied at the start of the experiment in 1997 and the second application, 2 years later in 1999. No compost was applied to the plots in 1998 and 2000 to evaluate the residual effects of the swine manure compost on soil quality. The experiment consisted of four replications of 16 plots $(6.5 \times 6 \mathrm{~m})$ arranged in randomized complete block design (RCBD). The arrangement of blocks was relative to the irrigation system to avoid probable soil variation due to irrigation.

\section{Field Management}

Cabbage (Brassica camperstris L.) and maize (Zea mays L.) were planted in a rotational system after the first application of swine manure composts. Cabbage were planted in October 1997, November 1998, and November 1999 and harvested in February 1998, April 1999, and April 2000, respectively. Maize was planted in June 1998 and August 1999, and harvested in September 1998 and October 1999, respectively. The maize of the third study year was planted in June 2000 but a typhoon destroyed all the maize plants in August 2000; therefore, we plowed all plants into the soil and then kept the soil surface bare until the maize of fourth study year was planted again in February 2001 and then harvested in July 2001.

The plant spacing was $50 \times 60 \mathrm{~cm}$ (130 plants per plot). No cover crop or green manure was added into the soil among growing seasons. Basal applications of chemical fertilizers were applied to all plots at the start of the experiment in 1997 and 1998 (48-31-49 and 48-35-98 kg/ha of N, P, and K, respectively) to promote early growth of the test crops. Herbicide was applied on the dates of planting and both insecticide and herbicide were applied about 6 and 8 weeks after planting. Weeding by hand was also carried out. Conventional tillage was conducted to $20-\mathrm{cm}$ depth by tandem disk or moldboard plow before seeding.

\section{Soil Quality Index Model}

The soil properties that were measured in this study were chosen as soil quality indicators (Table 2), with modification, from Mausbach and Seybold (1998). Because the application of swine manure composts to the rural soil may result in $\mathrm{Cu}$ and $\mathrm{Zn}$ accumulation in the soil surface, we used the availability of $\mathrm{Cu}$ and $\mathrm{Zn}$ (DTPA extractable) as indicators of the risk of

TABLE 1

Some properties of the soils used in this study

\begin{tabular}{|c|c|c|c|c|c|c|c|c|}
\hline $\begin{array}{l}\text { Depth } \\
(\mathrm{cm})\end{array}$ & $\mathrm{pH}^{*}$ & $\begin{array}{l}\text { O.C. } \\
(\%)\end{array}$ & Sand & $\begin{array}{l}\text { Silt } \\
(\mathrm{g} / \mathrm{kg})\end{array}$ & Clay & Texture & $\begin{array}{c}\text { Exchangeable bases }^{\dagger} \\
{[\mathrm{cmol}(+) / \mathrm{kg}]}\end{array}$ & $\begin{array}{c}\text { Available water } \\
{[\%(\mathrm{w} / \mathrm{w})]}\end{array}$ \\
\hline $20-40$ & 5.3 & 1.0 & 119 & 614 & 267 & Silt loam & 6.2 & 16.3 \\
\hline
\end{tabular}

*Soil: deionized water $=1: 1(\mathrm{w} / \mathrm{w})$.

${ }^{\dagger} \mathrm{NH}_{4} \mathrm{OAc}$ exchangeable. 
TABLE 2

The selected indicators, specific SSF, and parameters

\begin{tabular}{|c|c|c|c|c|c|c|c|c|}
\hline Indicators & Unit & $\mathrm{SSF}^{*, \dagger}$ & $\begin{array}{c}\text { Lower } \\
\text { threshold }\end{array}$ & Baseline & $\begin{array}{c}\text { Upper } \\
\text { threshold }\end{array}$ & $\begin{array}{c}\text { Lower } \\
\text { baseline }\end{array}$ & $\begin{array}{c}\text { Optimum } \\
\text { level }\end{array}$ & $\begin{array}{r}\text { Upper } \\
\text { baseline }\end{array}$ \\
\hline \multicolumn{9}{|l|}{ Chemical properties } \\
\hline $\mathrm{pH}\left(\mathrm{H}_{2} \mathrm{O}\right)$ & & 5 & 4 & - & 9 & 5.3 & 6.5 & 7.5 \\
\hline Organic C & $\%$ & 3 & 0.5 & 2 & 6.5 & - & - & - \\
\hline Available $\mathrm{K}$ & $\mathrm{mg} \mathrm{kg}^{-1}$ & 5 & 45 & - & 500 & 100 & 225 & 425 \\
\hline Available P & $\mathrm{mg} \mathrm{kg}^{-1}$ & 5 & 7.5 & - & 200 & 30 & 50 & 150 \\
\hline Extractable $\mathrm{Cu}$ & $\mathrm{mg} \mathrm{kg}^{-1}$ & 5 & 1 & - & 100 & 5.5 & 10 & 30 \\
\hline Extractable Zn & $\mathrm{mg} \mathrm{kg}^{-1}$ & 5 & 2 & - & 80 & 13.5 & 25 & 60 \\
\hline \multicolumn{9}{|l|}{ Physical properties } \\
\hline Bulk density & $\mathrm{mg} \mathrm{m}^{-3}$ & 9 & 1 & 1.4 & 1.8 & - & - & - \\
\hline Water-stable aggregates & $\%$ & 3 & 0 & 30 & 60 & - & - & - \\
\hline \multicolumn{9}{|l|}{ Biological properties } \\
\hline Microbial biomass $\mathrm{C}$ & $\mathrm{mg} \mathrm{kg}^{-1}$ & 3 & 78 & 350 & 700 & - & - & - \\
\hline Mineralizable N & $\mathrm{mg} \mathrm{kg}^{-1}$ & 3 & 0 & 50 & 100 & - & - & - \\
\hline
\end{tabular}

*Quadratic functions were used to fit three points (lower threshold, baseline, and upper threshold in both SSF3 and SSF9; lower threshold, baseline 1, and optimum in SSF5 for data lower than optimum value; optimum, baseline 2, and upper threshold for data not lower than optimum value).

†SSF modified from Mausbach and Seybold (1998); SSF 3 indicates "more is better", SSF 5 indicates "an optimum range", and SSF 9 indicates "less is better".

exposure to high environmental concentration of $\mathrm{Cu}$ and $\mathrm{Zn}$. To evaluate the effects of swine manure compost application on soil quality, we evaluated the changes of the indicators between treatments and observed the trend of each indicator under a specific treatment over time. Application of $\mathrm{N}$-enriched and $\mathrm{P}$ materials might lead to $\mathrm{NO}_{\mathrm{x}}$ emissions, nitrate leaching, and eutrophication of surface waters. We used available soil $\mathrm{N}$ and available soil $\mathrm{P}$ content as indicators for this possibility. For the soil scoring function (SSF) of these two indicators, the SSF value was calculated as 0 if the determined values are higher than upper threshold value, which indicate that the soil was under high potential environmental detriments.

We followed the framework described by Andrews et al. (2004) and Karlen et al. (2001) to model the SQI based on the data we obtained from this present experiment. The framework used in this study consisted of three steps including indicator selection, indicator interpretation, and integration of all indicators into an a SQI value. The selected indicators, specific SSF, and parameters of this study are given in Table 2 and Fig. 1. In SSF 3 and SSF 9, we used quadratic functions to fit 3 points (lower threshold, baseline, and upper threshold). In SSF 5, we used a quadratic function to fit lower threshold, baseline 1 , and optimum value for soil data that is lower than optimum value. We also used another quadratic function to fit the optimum, baseline 2, and upper threshold value for soil data that are higher than optimum value. An example calculation of SSF for DTPA-extractable $\mathrm{Zn}$ is shown in Fig. 2.

Table 3 shows the model for assessing SQI that we developed with after several trials using different indicators and threshold values based on our soil database and research experience in Taiwan, and for the specific purpose of evaluating the impact of swine manure application on soil quality. The standardized values $(0-1)$ of soil indicators were given specific weights and then combined into one simple value, the SQI. The total weight of all indicators is 1 . Thus, the values of SQI range between 0 and 1 . The weightings were given subjectively. As we are concerned, the physical, chemical, and biological properties are given almost equal weighting to emphasize the equal importance of these three categories of soil properties in their contribution to soil functions (Weight 1). Each indicator was assigned a sub-weight factor (Weight 2) that might differ from the weighting of others to emphasize the individual contribution to specific category of soil properties. We calculated the SQI with five completed data sets from Eq. (1):

$$
\mathrm{SQI}=\Sigma\left(\mathrm{S}_{\mathrm{i}} \times \mathrm{W}_{\mathrm{i}}\right)
$$

where $S_{\mathrm{i}}$ represents the scored indicator value and $W_{\mathrm{i}}$ is the weighted index of each indicator which equals to Weight $1 \times$ Weight 2 . Because 

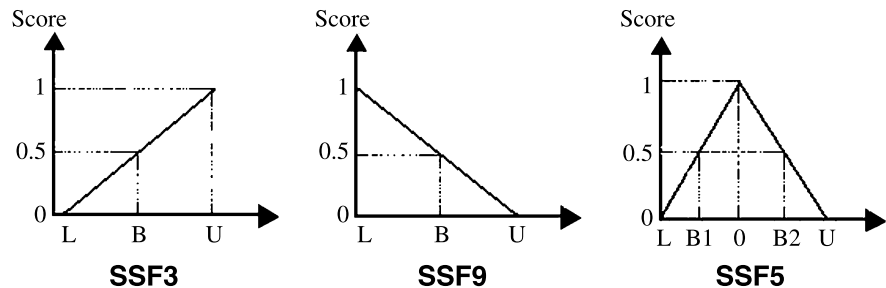

Fig. 1. General shape of SSF for soil quality evaluation. Note: SSF3 indicates more value is better, SSF5 indicates an optimum value is better, and SSF9 indicates less value is better. (1) SSF3 score: L (lower threshold) $=0$, $B($ baseline $)=0.5$, and U (upper threshold) $=1 ;(2)$ SSF5 score: $L($ lower threshold $)=0, B 1$ (lower baseline $)=0.5$, $O$ (optimum) $=1$, B2 (upper baseline) $=0.5$, and $U$ (upper threshold) $=0$; and (3) SSF9 score: $L$ (lower threshold) $=1$, $\mathrm{B}($ baseline $)=0.5$, and $\mathrm{U}$ (upper threshold $)=0$.

the $S_{\mathrm{i}}$ and $W_{\mathrm{i}}$ values are standardized from 0 to 1 , the SQI values are also calculated as 0 to 1 .

\section{Soil Sampling and Analyses}

Surface $(0-20 \mathrm{~cm})$ and sub-surface $(20-40$ $\mathrm{cm})$ soil samples were taken before the application of composts and after harvesting the crops. Three soil samples from different portions in each plot were collected and mixed into one composite sample for chemical and biological analyses. These included soil $\mathrm{pH}$ (soil: water $=1: 1$ ), organic carbon (Nelson and Sommers, 1982), available P (Bray- $\left.\mathrm{P}_{1}\right)$, available $\mathrm{K}$ (Mehlich method), mineralizable $\mathrm{N}$ (Waring and Bremner, 1964), microbial biomass C (fumigation-incubation method), and available $\mathrm{Cu}$ and $\mathrm{Zn}$ (0.005 $M$ DTPA extractable at $\mathrm{pH}$ 7.3). In addition, soil cores and soil blocks were collected and analyzed for bulk density (Blake and Hartge, 1986) and water-stable aggregates with a size of 1.4-2.83 mm (Arshad et al., 1996), respectively. Tissue samples of maize and cabbage were collected a few days before each harvest for yield calculation and the analysis of

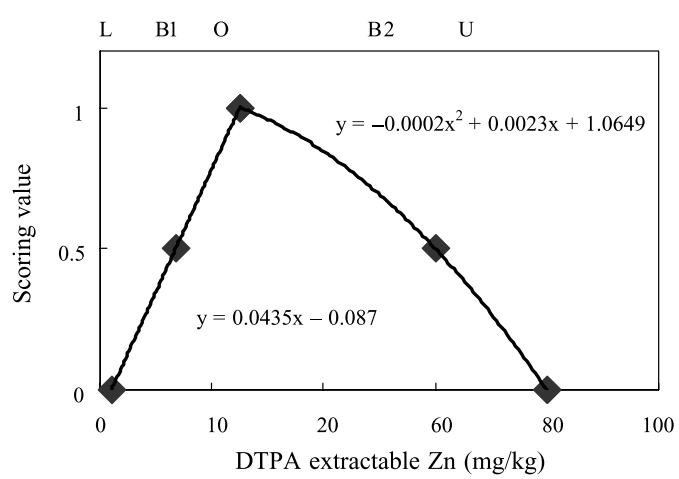

Fig. 2. An example of SSF for DTPA-extractable Zn (refer to SSF5 in Fig. 1).
$\mathrm{Cu}$ and $\mathrm{Zn}$ concentrations in the grains, cobs, and leaves of maize and in the edible portion of cabbage. Tissue concentrations of $\mathrm{Cu}$ and $\mathrm{Zn}$ were analyzed by flame atomic absorption spectrophotometry after digestion with $\mathrm{H}_{2} \mathrm{SO}_{4} /$ $\mathrm{HClO}_{4}$ (Novozamsky et al., 1983).

Analysis of variance (ANOVA) was performed for each observed indicators and the integrated calculated SQI to compare the statistical differences between treatments with GLM progress (SAS Institute, 1995). The mean comparisons of significant effects were done with Duncan's new multiple range test at the 95\% confidence level $(P<0.05)$.

\section{RESULTS AND DISCUSSION}

Our results revealed that medium and high manure compost application significantly increased the values of the soil quality indicators of the surface soil except for bulk density (Figs. 3 to 6). No effects of the treatments were observed on

TABLE 3

The SQI model in this study

\begin{tabular}{|c|c|c|c|c|}
\hline $\begin{array}{l}\text { Soil } \\
\text { function }\end{array}$ & Weight 1 & Indicators & Weight 2 & $\begin{array}{r}\text { Weighted } \\
\text { index }^{\dagger}\end{array}$ \\
\hline \multirow{2}{*}{$\begin{array}{l}\text { Physical } \\
\text { properties }\end{array}$} & \multirow[t]{2}{*}{0.33} & Bulk density & 0.5 & 0.165 \\
\hline & & $\begin{array}{r}\text { Water-stable } \\
\text { aggregates }\end{array}$ & 0.5 & 0.165 \\
\hline \multirow{6}{*}{$\begin{array}{l}\text { Chemical } \\
\text { properties }\end{array}$} & \multirow[t]{6}{*}{0.34} & Organic C & 0.4 & 0.136 \\
\hline & & $\mathrm{pH}\left(\mathrm{H}_{2} \mathrm{O}\right)$ & 0.2 & 0.068 \\
\hline & & Available K & 0.1 & 0.034 \\
\hline & & Available P & 0.1 & 0.034 \\
\hline & & Extractable $\mathrm{Cu}$ & 0.1 & 0.034 \\
\hline & & Extractable Zn & 0.1 & 0.034 \\
\hline \multirow[t]{2}{*}{$\begin{array}{l}\text { Biological } \\
\text { properties }\end{array}$} & \multirow[t]{2}{*}{0.33} & $\begin{array}{l}\text { Microbial } \\
\text { biomass } \mathrm{C}\end{array}$ & 0.5 & 0.165 \\
\hline & & Mineralizable N & 0.5 & 0.165 \\
\hline tal & 1.00 & & & 1.00 \\
\hline
\end{tabular}

${ }^{\dagger}$ Weighted index $=$ Weight $1 \times$ Weight 2 . 
A

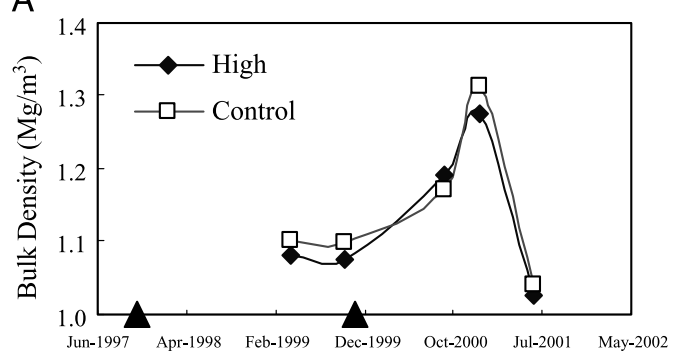

C

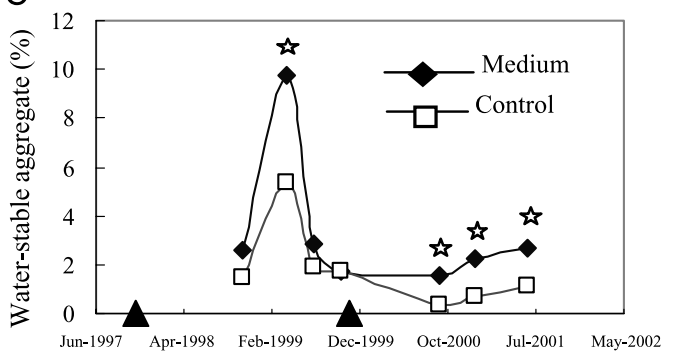

B

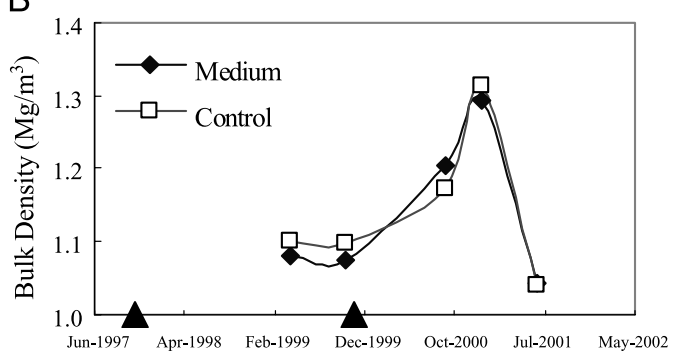

D

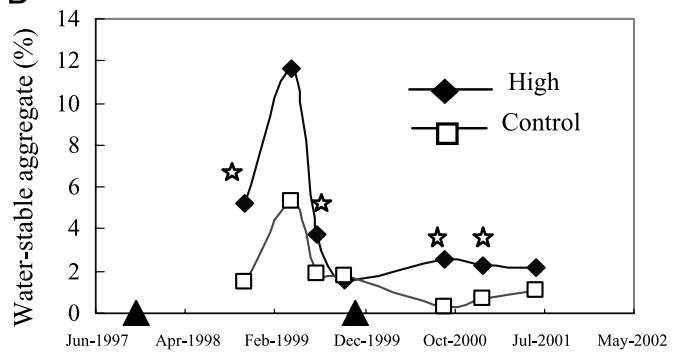

Fig. 3. Comparison of physical indicators between treatments over time. is Point value shown by this symbol indicates significant difference compared with control treatment on specific date $(P<0.05)$. $\mathbf{\Delta}$ The application date of compost.

the indicators for the sub-soil (data not shown) indicating that the sub-soil is less subject to the effects of compost application in the short term. Soil quality usually changes first near the soil surface, and then changes at greater soil depths over time. Hence, to save time, minimize cost, and observe the effect of certain management instantaneously, soil quality assessment may be best done for the surface soil preferentially.

\section{Physical Indicators}

Soil bulk density of the surface soil was lower than that of the sub-soil but it did not differ among treatments. Bulk density indicates the weight of soil particles in a given volume and thus, it reflects the degree of porosity or compaction of the soil. Tillage may temporarily loosen the soil surface but its long-term effect increases soil compaction and soil bulk density (Brady and Weil, 2002). In this study, tillage and other field operations seemed to have masked the effect of compost on buck density resulting in no significant differences among treatments (Figs. 3a and b). Higher temperature and intensively tillage of surface soil may result in rapid decomposition of organic matter. Therefore, the effect of application of organic matter-enriched material on bulk density may be not significant. It thus seems that for intensively cultivated medium textured soils in sub-tropical zone, bulk density may not reflect the effects of compost application on the soil quality.

Aggregate stability indicates soil stability and the physical condition of the soil for aeration, erosion, and root growth (Tisdall and Oades, 1982). The soil used in this study had very low percentage of water-stable macro-aggregates $(1.4-2.83 \mathrm{~mm})$, which can be ascribed to the initially low organic matter content, silt loam texture, and prolonged disturbance by intensive cultivation. The results showed that application of medium and high rates of manure compost significantly increased the aggregation of the soil relative to the control (Figs. $3 \mathrm{c}$ and d). Whalen et al. (2003) examined the effects of applying composts on aggregate stability in conventional and no-tillage systems. Their findings indicated rapid improvements in the aggregation of a silt loam soil in the first 2 years after compost application and the adoption of no-tillage practices, but not for conventional practices. Suitable intensity of tillage may reduce bulk density of soils and provide better aeration and water 
conductivity for microbe and plant roots. However, excessive tillage in intensive agriculture is common in Taiwan and results in faster decomposition of O.M., and then lower level of O.M. content and aggregate stability. To improve soil physical properties, a reduction in the intensity of tillage practices may be necessary while the swine manure compost application has low effi- ciency on soil bulk density and water-stable aggregate stability.

\section{Chemical Indicators}

Organic C of the surface soil was significantly increased by medium and high rates of manure compost application, which lasted for about 2 years from application (Figs. $4 \mathrm{a}$ and b).
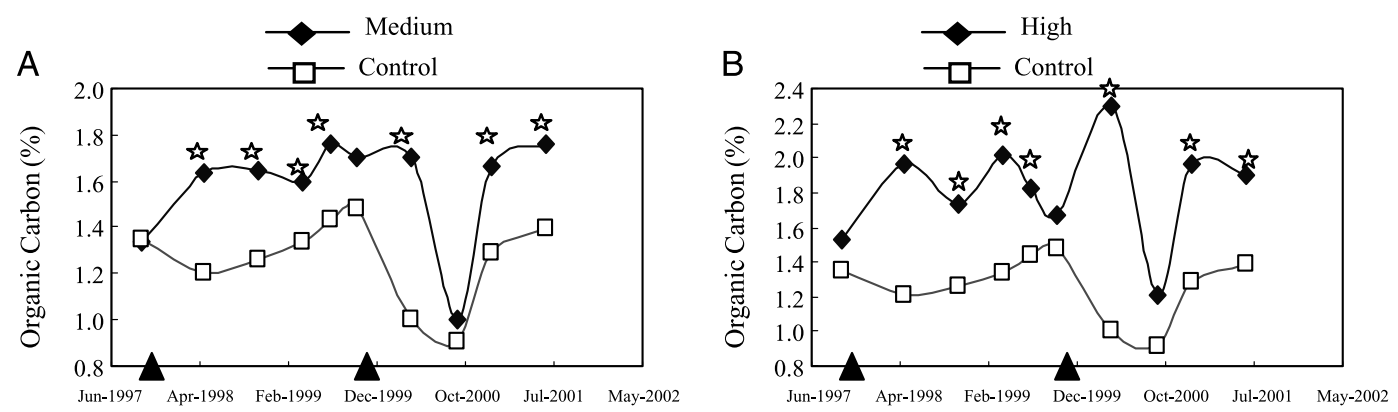

C

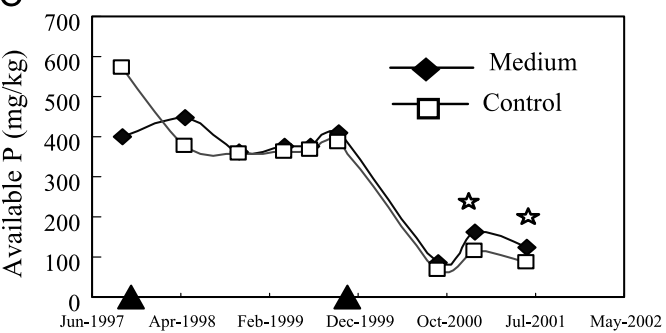

D

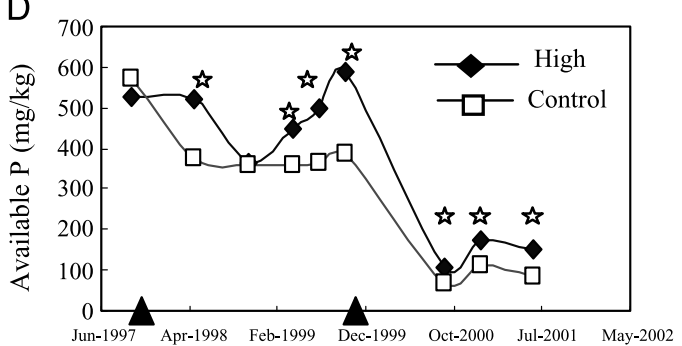

E
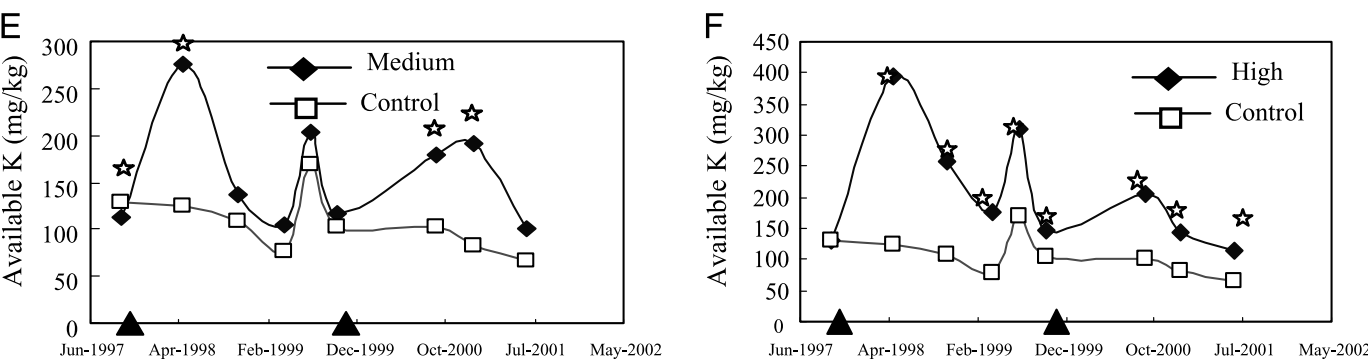

G
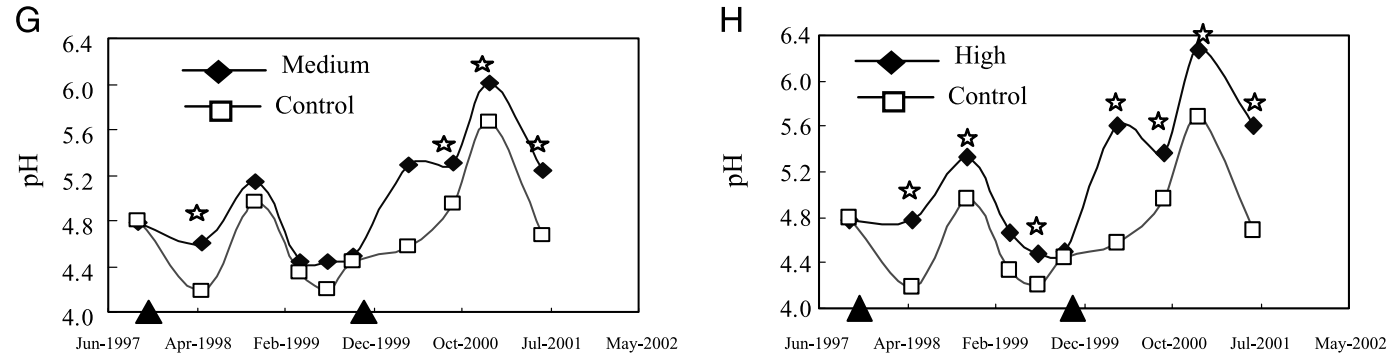

Fig. 4. Comparison of chemical indicators between treatments over time. is Point value shown by this symbol indicates significant difference compared with control treatment on specific date $(P<0.05)$. $\mathbf{\Delta}$ The application date of compost. 
A

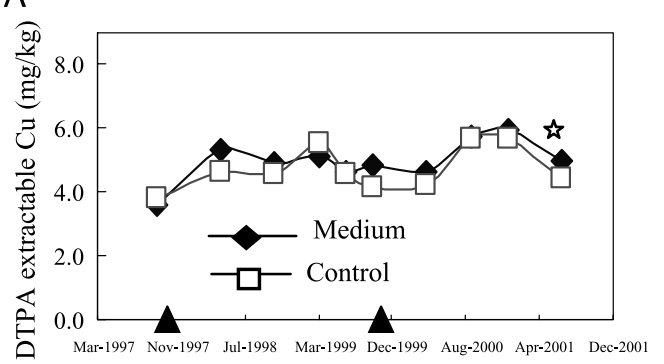

C

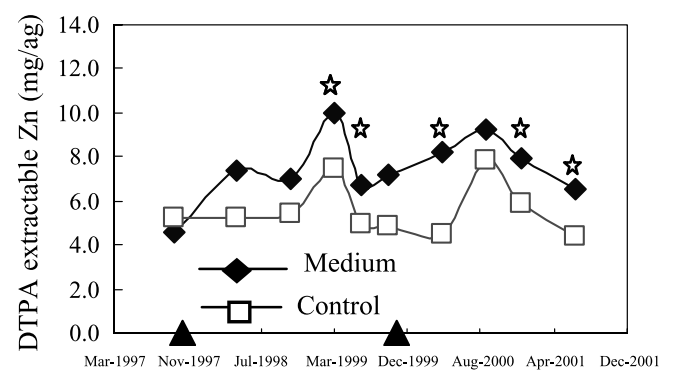

B

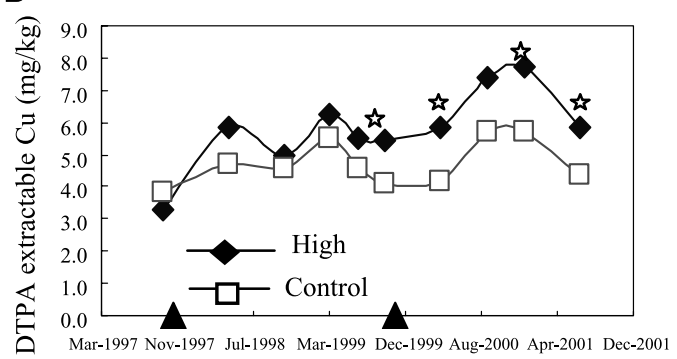

D

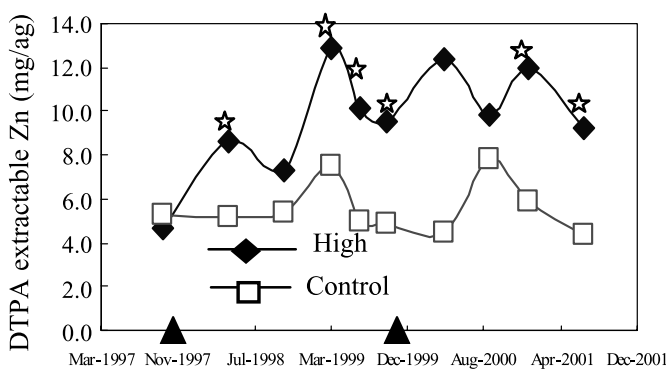

Fig. 5. Comparison of extractable $\mathrm{Cu}$ and $\mathrm{Zn}$ between treatments over time. 2 Point value shown by this symbol indicates significant difference compared with control treatment on specific date $(P<0.05)$. $\Delta$ The application date of compost.

However, the amount of organic $\mathrm{C}$ in the soil was still low $(<2.5 \%)$ even at high levels of compost application probably due to rapid decomposition by decomposing microorganisms. Harris et al. (1996) suggested that $4-6 \%$ of organic C in soils is appropriate to maintain good soil condition. Published results suggest that continuous manure compost application at a rate of more than 30 tons $\mathrm{ha}^{-1}$ is necessary to build up the organic $\mathrm{C}$ content of the soil to the ideal level to maintain good soil structure, high soil biodiversity, and high crop productivity (Gregorich et al., 1995; Studdert et al., 1997). Our data also agree with findings that the build up of organic $\mathrm{C}$ in the soil due to manure application is slow (Merbach et al., 2000). Hao et al. (2003) found small but significant increases in soil carbon after 25 years of cattle manure applications. Kaur et al. (2005) observed a significant increase in organic $\mathrm{C}$ after 7 years of manure application. As with the discussion in the section of soil physical indicators, intensively tillage may result in rapid decomposition of O.M., and thus the conclusion that in intensive agriculture, a reduction in the intensity of tillage practices seems to be necessary to improve the build up of organic C.
The concentration of available $\mathrm{P}$ was significantly increased by medium and high rates of manure application relative to the control (Figs. $4 \mathrm{c}$ and d). However, as in the control, the amount of available $\mathrm{P}$ also decreased in receiving manure compost. This indicates that $\mathrm{P}$ in the swine manure compost occurred mostly in an organic form that was not readily available. A similar result was reported by Meek et al. (1997). Thus, supplemental application of chemical $\mathrm{P}$ fertilizer is necessary to satisfy the $\mathrm{P}$ requirement of the crops during the early stage of growth.

Available $\mathrm{K}$ of the surface soil in plots receiving the medium rate of compost was significantly higher than in the control plot for about 1 year after application where as the higher available $\mathrm{K}$ in plots that received high rate of compost lasted for about 2 years (Figs. 4e and f). Bulluck et al. (2002) noted an increase in available $\mathrm{K}$ in soils amended with organic waste consisting of composted crop waste and cattle manure. This result suggests that $\mathrm{K}$ in swine manure compost is in readily available form such that its application resulted in significant increase in available soil K. Excess manure application may thus result in very high amounts 
of available $\mathrm{K}$ that could reduce $\mathrm{Ca}$ and $\mathrm{Mg}$ uptake by plants (Tisdale et al., 1985). The SSF parameters for available $\mathrm{K}$ were raised compared to that proposed by Mausbach and Seybold (1998) due to the high rainfall in Taiwan, which could cause considerable leaching and thus minimize excessive supply of $\mathrm{K}$ in the soil. Application of 40 tons $\mathrm{ha}^{-1}$ of compost per year can provide sufficient $\mathrm{K}$ for crop production without significant negative effect in relation to $\mathrm{K}$ nutrition.

Medium and high manure compost application significantly increased surface soil $\mathrm{pH}$ by $0.2-0.8 \mathrm{U}$ relative to the control (Figs. $4 \mathrm{~g}$ and $\mathrm{h}$ ). In addition, there was an increasing trend in soil $\mathrm{pH}$ with time indicating the liming effect of swine manure compost. This result agrees with that of Shen and Shen (2001) showing an increase in soil $\mathrm{pH}$ as a result of pig manure application. They attributed such $\mathrm{pH}$ increase to the considerable amounts of $\mathrm{K}$, $\mathrm{Ca}$, and $\mathrm{Mg}$ in pig manure. To raise soil $\mathrm{pH}$ up to 6.5 , successive application of 40 tons $^{-1}$ of compost per year in this study site is necessary.

DTPA-extractable $\mathrm{Cu}$ and $\mathrm{Zn}$ in soil indicate the bioavailability and potential toxicity of these micronutrients to plants. Previous research has shown that the concentrations of DTPAextractable $\mathrm{Cu}$ and $\mathrm{Zn}$ in soils higher than the critical levels of 10 and $25 \mathrm{mg} \mathrm{kg}^{-1}$ result in crop yield decline (Li et al., 1987). Although the swine manure composts we used in this present study had high total $\mathrm{Cu}$ and $\mathrm{Zn}$ concentrations, the DTPA-extractable concentrations of $\mathrm{Cu}$ and $\mathrm{Zn}$ in the treated soil were still below the abovementioned critical levels, even under the high rate of manure compost application (Fig. 5a-d). It seems that the application of 120 tons ha ${ }^{-1}$ of swine manure compost can provide moderate amounts of bio-available $\mathrm{Cu}$ and $\mathrm{Zn}$ for crop production although higher concentrations of $\mathrm{Cu}$ and $\mathrm{Zn}$ may be released from the material into the soil system after complete decomposition. Long-term experiments are needed to determine how stable organic compounds in the soil influence the bioavailability of heavy metals. Furthermore, it should be noted that although $\mathrm{Cu}$ and $\mathrm{Zn}$ did not accumulate to harmful levels in this study, longterm applications of manure may reach such harmful levels in the soil.

EC was not chosen as an indicator in this study because of the relative low proportion of
A

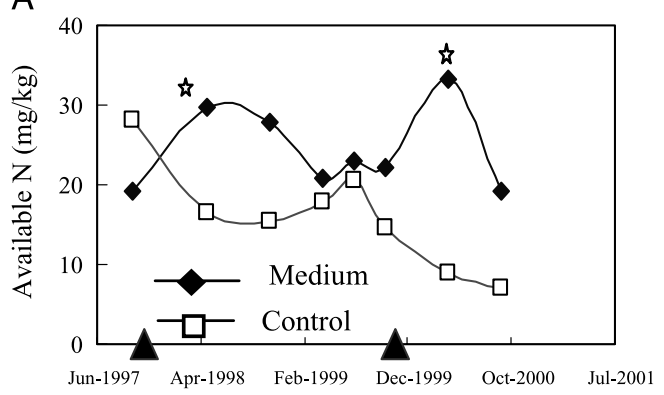

C

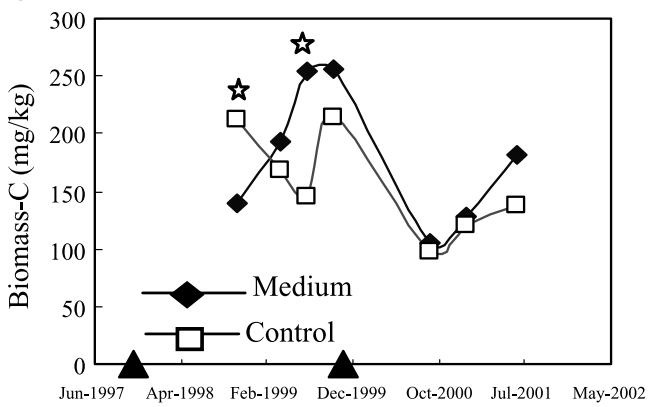

B

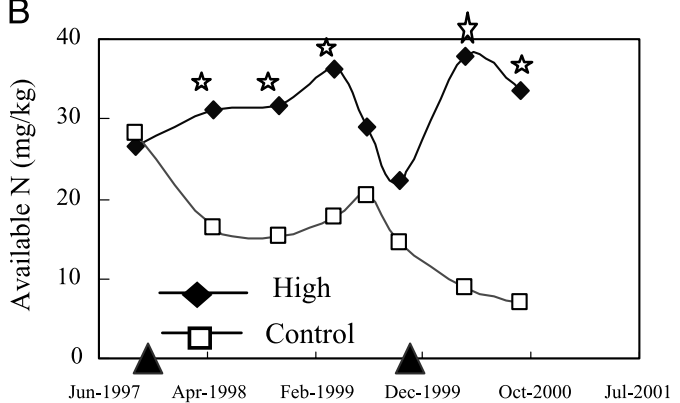

D

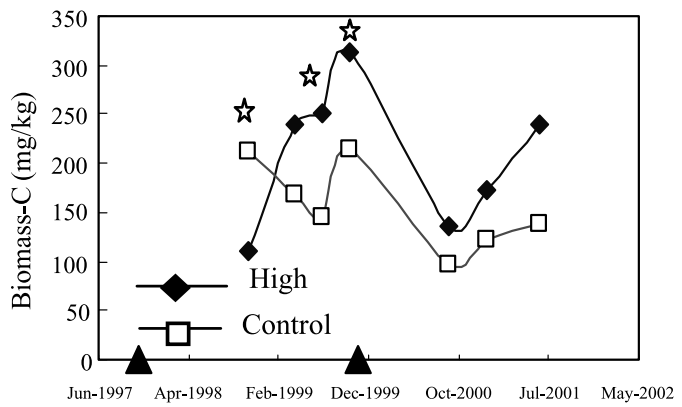

Fig. 6. Comparison of biological indicators between treatments over time. is Point value shown by this symbol indicates significant difference compared with control treatment on specific date $(P<0.05)$. $\Delta$ The application date of compost. 
compost to soil $(<8.5 \%$ in total amount) and high precipitation during the study. However, for a long-term study and at high application rate, swine manure compost may accumulate soluble salts. Thus, EC should be an important indicator for the evaluation of soil quality. Moreover, high nitrate levels under wet conditions can lead to nitrate leaching and $\mathrm{NO}_{\mathrm{x}}$ emission and high $\mathrm{P}$ levels can contribute to eutrophication of surface water. These concerns should be considered for further research.

\section{Biological Indicators}

Mineralizable $\mathrm{N}$ is considered to be a useful integration of chemical, physical, and biological aspects of soil quality because it combines both the accumulation of $\mathrm{N}$ through previous biological activity, the present organic status of the soil, and the current $\mathrm{N}$ mineralization activity of the soil microorganisms (Sparling, 1997). Our results revealed that medium and high rates of manure compost application significantly increased the mineralizable $\mathrm{N}$ of the surface soil (Figs. 6a and b). The greater increase in mineralizable $\mathrm{N}$ in the soil after the second manure compost application implies that application of the organic material every 2 years can maintain sufficient levels of inorganic $\mathrm{N}$ in the soil. Frequent and high rates of manure application, for instance yearly, may lead to nitrate pollution of the groundwater. Castellanos and Pratt (1981) reported that $80 \%$ of $\mathrm{N}$ in manure could be mineralized a few weeks after land application. In this study, we found that the mineralizable $\mathrm{N}$ was significantly higher than that of control treatment even several months after swine manure compost application. It is difficult to calculate the $\mathrm{N}$ mineralized portion because the large sampling period and scale in 4 years and the lack of total organic $\mathrm{N}$ data.

Soil microbial biomass carbon (SMB-C) is also an important indicator of biological condition and serves as a representative status of both nutrient and water content. It is also an indicator of changes in the soil (e.g., Gregorich et al., 1997). Figs. 6c and d show significantly higher SMB-C in soil applied with medium and high rates of manure compost several months after the first application. It also shows large temporal variation in the SMB-C reflecting the highly dynamic nature of microbial activity in the soil in response to changes in soil conditions (Parkin, 1993; Spedding et al., 2004). The large temporal variation can be ascribed to changes in soil physical and chemical conditions.
Spedding et al. (2004) reported that the frequently changing soil conditions may occur throughout the growing season that will promote changes in the microbial biomass. They stressed that using microorganisms as a measure of management-induced changes must be used with caution because temporal changes may be greater than the effect of management.

\section{Crops Response}

Yields of cabbage and maize, grown in rotation, as affected by swine manure compost application, are shown in Table 4. During the first cropping season, the low and medium rates of manure compost significantly increased the yield of cabbage where as the high application rate resulted in significantly lower yield compared to the control treatment. The latter may be attributed to the excess of nutrients during the early decomposition of the organic material. In the subsequent two cropping seasons, all rates of compost application increased the yield of cabbage although the low rate was not significantly different from the control during the second cropping season. Regarding maize, manure compost application seemed to increase the yield of maize although it was significant only during the first cropping season and not in the second and third. Using a quadratic regression model, we determined that the optimum rate of compost application for maximum cabbage and maize yields ranged from 30 to 60 tons ha ${ }^{-1}$ per year during the investigation period.

Swine manure compost application did not cause excessive accumulation of $\mathrm{Cu}$ and $\mathrm{Zn}$ in either crop. $\mathrm{Cu}$ and $\mathrm{Zn}$ concentrations in the tissues of maize and cabbage were not significantly different from the control (data not shown). Although application of metal-rich compost may result in higher residual metal content in the soil, uptake by plants is reduced by the formation of complexes between the organic substance and the metals (Düring and Gäth, 2002; Shuman et al., 2001). In this study, we found that total and DTPA-extractable $\mathrm{Cu}$ and $\mathrm{Zn}$ contents of the soil, as well as the plant concentrations of both elements, were within the normal range of concentrations recommended for Taiwan soils (Chen, 1999). This indicates that two applications of swine manure compost proposed to improve soil quality and increase crop yields in 4 years did not pose any risk of heavy $\mathrm{Cu}$ and $\mathrm{Zn}$ pollution to the soil despite the fact that the total amount 
TABLE 4

Yields (tons/ha)* of cabbage and corn effected by the application of swine manure composts

\begin{tabular}{lcccccc}
\hline Treatment & $\begin{array}{c}\text { Cabbage, } \\
\text { February 1998 }\end{array}$ & $\begin{array}{c}\text { Maize, } \\
\text { September 1998 }\end{array}$ & $\begin{array}{c}\text { Cabbage, } \\
\text { April 1999 }\end{array}$ & $\begin{array}{c}\text { Maize, } \\
\text { October 1999 }\end{array}$ & $\begin{array}{c}\text { Cabbage, } \\
\text { June 2000 }\end{array}$ & $\begin{array}{c}\text { Maize, } \\
\text { July 2001 }\end{array}$ \\
\hline Control & $33.69^{\mathrm{b}, \dagger}$ & $6.37^{\mathrm{c}}$ & $38.38^{\mathrm{b}}$ & $7.56^{\mathrm{a}}$ & $8.21^{\mathrm{b}}$ & $6.20^{\mathrm{a}}$ \\
Low & $38.21^{\mathrm{a}}$ & $6.90^{\mathrm{bc}}$ & $40.77^{\mathrm{ab}}$ & $8.11^{\mathrm{a}}$ & $17.75^{\mathrm{a}}$ & $7.27^{\mathrm{a}}$ \\
Medium & $36.51^{\mathrm{a}}$ & $7.62^{\mathrm{a}}$ & $42.56^{\mathrm{a}}$ & $7.85^{\mathrm{a}}$ & $19.88^{\mathrm{a}}$ & $7.51^{\mathrm{a}}$ \\
High & $30.28^{\mathrm{c}}$ & $7.44^{\mathrm{ab}}$ & $44.29^{\mathrm{a}}$ & $8.08^{\mathrm{a}}$ & $19.61^{\mathrm{a}}$ & $7.62^{\mathrm{a}}$ \\
\hline
\end{tabular}

*Fresh weight.

${ }^{\dagger}$ Values followed by the same letter within each column are not significantly different at $P=0.05$.

of compost in the high application treatment was 180 tons $\mathrm{ha}^{-1}$.

\section{Soil Quality Indices}

SQI are simple values that indicate the alteration of soil characteristics under different management systems and the changing trends of soil properties. According to Karlen et al. (2001), SQI scores are relative and not absolute. They also emphasized the better accuracy of indices developed for specific soil quality assessment projects as these rely on analytical laboratory data. Our results showed that increasing rates of manure compost application led to an increasing trend in SQI values, although these were not significantly different among the various manure application rates (Table 5). However, the SQI values in plots that received the highest rate of application were significantly higher than those from control plots. The increase in SQI values seems to be in agreement with the general increase in crop yield with increasing rates of manure application. Both of these observations reflect the positive changes in soil parameters as a result of compost application including an increase in soil available nutrient contents $(\mathrm{N}, \mathrm{P}, \mathrm{K}, \mathrm{Cu}$, and $\mathrm{Zn})$, organic matter content, water-stable aggregates, and soil $\mathrm{pH}$. More importantly, it revealed that the SQI model correctly reflected the improvement in soil quality and the increase in crop productivity. The results also imply that under the prevailing conditions in Taiwan, short-term application of swine manure composts at rates lower than 40 tons $\mathrm{ha}^{-1}$ year ${ }^{-1}$ may not greatly change the soil quality due to combined effects of cultivation, high precipitation and temperature, and high decomposition rate of applied compost. Application of 40-60 tons ha ${ }^{-1}$ year $^{-1}$ of manure compost is proposed to improve the soil quality and to increase crop yields. However, nitrate leaching may occur under high rates and prolonged application of compost. Thus, we recommend that more long-term studies be conducted to assess the effects of applying manure compost and other contaminant-enriched solid wastes on soil and groundwater quality.

\section{CONCLUSIONS}

Application of swine manure composts improved soil quality of the surface soil and increased the yields of maize and cabbage. The residual effects of applying manure compost on the yield of the crops were better than that of the conventional method using chemical fertilizers. Application of manure compost did not raise the concentrations of $\mathrm{Cu}$ and $\mathrm{Zn}$ in the soil as well as in the tissues of maize and cabbage to harmful levels.

Improvement in soil quality and an increase in the yield of the crops were shown by the significant increase in the values of the soil indicators and consequently of the SQI relative

TABLE 5

Soil quality indices calculated using the SQI model

\begin{tabular}{lccccc}
\hline Treatment & April 1999 & October 1999 & September 2000 & January 2001 & July 2001 \\
\hline Control & $0.339^{\mathrm{c},}$ & $0.342^{\mathrm{c}}$ & $0.299^{\mathrm{b}}$ & $0.302^{\mathrm{c}}$ & $0.312^{\mathrm{b}}$ \\
Low & $0.417^{\mathrm{ab}}$ & $0.350^{\mathrm{bc}}$ & $0.325^{\mathrm{ab}}$ & $0.399^{\mathrm{ab}}$ & $0.344^{\mathrm{b}}$ \\
Medium & $0.390^{\mathrm{bc}}$ & $0.389^{\mathrm{ab}}$ & $0.346^{\mathrm{b}}$ & $0.362^{\mathrm{b}}$ & $0.378^{\mathrm{ab}}$ \\
High & $0.452^{\mathrm{a}}$ & $0.404^{\mathrm{a}}$ & $0.370^{\mathrm{a}}$ & $0.431^{\mathrm{a}}$ & $0.425^{\mathrm{a}}$ \\
\hline
\end{tabular}

${ }^{\dagger}$ Values followed by the same letter within each column are not significantly different at $P=0.05$. 
to the control. Thus, the SQI seems to be an effective tool to assess the effect of manure compost application on soil quality. The soil indicators that we found effective for that purpose include aggregate stability, organic carbon content, soil $\mathrm{pH}$, available $\mathrm{N}, \mathrm{P}$, and $\mathrm{K}$, extractable $\mathrm{Cu}$ and $\mathrm{Zn}$, and microbial biomass. All these soil properties were significantly increased by manure compost application.

Application of $40-60$ tons $\mathrm{ha}^{-1}$ year $^{-1}$ of manure compost is proposed to improve the soil quality and increase yield of maize and cabbage under a rotation system in Taiwan. However, nitrate leaching may occur at high rates and prolonged application of compost. Thus, we recommend that more long-term studies be conducted to assess the effects of applying manure compost and other contaminant-enriched solid wastes on soil and groundwater quality.

\section{ACKNOWLEDGMENTS}

The authors thank the Council of Agriculture (COA) of the Republic of China for financially supporting this research under Contract No. 87AST-1.6-L-05(4), 88AST-1.6-L-01 (11-4), and 89AST-1.4-L-61(8). We also thank the graduate students of the Soil Survey and Classification Laboratory, Department of Agricultural Chemistry, National Taiwan University, Taipei, for their help during soil sampling activities.

\section{REFERENCES}

Andrews, S. S., D. L. Karlen, and C. A. Cambardella. 2004. The soil management assessment framework: A quantitative soil quality evaluation method. Soil Sci. Soc. Am. J. 68:1945-1962.

Arshad, M. A., B. Lowery, and B. Grossman. 1996. Physical tests for monitoring soil quality. In: Methods for assessing soil quality. J. W. Doran and A. J. Jones (eds.). SSSA Spec. Publ. 49, Madison, pp. 123-141.

Blake, G. R., and K. H. Hartge. 1986. Bulk density. In: Methods of soil analysis: Part I. Physical and mineralogical methods, 2nd ed. A. Klute (ed.). Agron. Monogr. 9, Madison, pp. 363-376.

Brady, N. C., and R. R. Weil. 2002. The nature and properties of soils, 14th ed. Prentice-Hall, New Jersey.

Bulluck, III, L. R., M. Brosius, G. K. Evanylo, and J. B. Ristaino. 2002. Organic and synthetic fertility amendments influence soil microbial physical and chemical properties on organic and conventional farms. Appl. Soil Ecol. 19:147-160.

Carter, M. R., E. G. Gregorich, D. W. Anderson,
J. W. Doran, H. H. Janzen, and F. J. Pierce. 1997. Concepts of soil quality and their significance. In: Soil quality for crop production and ecosystem health. E. G. Gregorich and M. R. Carter (eds.). Developments in Soil Science 25, Elsevier, Amsterdam, pp. 1-19.

Castellanos, J. Z., and P. F. Pratt. 1981. Mineralization of manure nitrogen-correlation with laboratory indexes. Soil Sci. Soc. Am. J. 45:354-357.

Chen, Z. S. 1999. Selecting indicators to evaluate soil quality. Extension Bulletin 473, Food and Fertilizer Technology Center (FFTC), Taipei, Taiwan.

Chen, Z. S., and S. S. Yang. 1996. Chinese Taiwan. In: A global atlas of wastewater sludge and biosolids use and disposal. P. Matthews (ed.). International Association of Water Quality, Scientific and Technical Report No. 4, IAWQ, London, pp. 35-46.

Doran, J. W., and T. B. Parkin. 1994. Defining and assessing soil quality. In: J. W. Doran, et al. (eds.). Defining soil quality for a sustainable environment. SSSA Press, Madison, pp. 3-21.

Doran, J. W., M. Sarrantonio, and M. A. Liebig. 1996. Soil health and sustainability. Adv. Agron. 56:1-54.

Düring, R. A., and S. Gäth. 2002. Utilization of municipal organic wastes in agriculture: Where do we stand, where do we go? J. Plant Nutr. Soil Sci. 165:544-556.

Gregorich, E. G., D. A. Angers, C. A. Campbell, M. R. Carter, C. F. Drury, B. H. Ellert, P. H. Groenevelt, D. A. Holmstrom, C. M. Monreal, H. W. Rels, R. P. Voroney, and T. J. Vyn. 1995. Changes in soil organic matter. In: The health of our soils: Toward sustainable agriculture in Canada. D. F. Acton and L. J. Gregorich (eds.). Centre for Land and Biological Resources Research, Research Branch, Agriculture and Agri-Food, Canada, pp. 41-50.

Gregorich, E. G., M. R. Carter, J. W. Doran, C. E. Pankhurst, and L. M. Dwyer. 1997. Biological attributes of soil quality. In: Soil quality for crop production and ecosystem health. E. G. Gregorich and M. R. Carter (eds.). Developments in Soil Science 25, Elsevier, Amsterdam, pp. 81-113.

Hao, X., C. Chang, G. R. Travis, and F. Zhang. 2003. Soil carbon and nitrogen response to 25 annual cattle manure applications. J. Plant Nutr. Soil Sci. 166:239-245.

Harris, R. F., D. L. Karlen, and D. J. Mulla. 1996. A conceptual framework for assessment and management of soil quality and health. In: Method for assessing soil quality. J. W. Doran and A. J. Jones (eds.). SSSA Spec. Publ. No. 49. Madison, pp. 61-82.

Kaur, K., K. K. Kapoor, and A. P. Gupta. 2005. Impact of organic manures with and without mineral fertilizers on soil chemical and biological properties under tropical conditions. J. Plant Nutr. Soil Sci. 168:117-122. 
Karlen, D. L., and D. E. Stott. 1994. A framework for evaluating physical and chemical indicators of soil quality. In: Defining soil quality for a sustainable environment. J. W. Doran, D. C. Coleman, D. F. Bezdicek, and B. A. Stewart (eds.). SSSA Press, Madison, pp. 53-72.

Karlen, D. L., M. J. Mausbach, J. W. Doran, R. G. Cline, R. F. Harris, and G. E. Schuman. 1997. Soil quality: A concept, definition, and framework for evaluation. Soil Sci. Soc. Am. J. 61:4-10.

Karlen, D. L., S. S. Andrews, and J. W. Doran. 2001. Soil quality: Current concepts and applications. Adv. Agron. 74:1-40.

L'Herroux, L., R. S. Le, P. Appriou, and J. Martinez. 1997. Behavior of metals following intensive pig slurry applications to a natural field treatment process in Brittany (France). Environ. Pollut. 97: 119-130.

Li, G. C., Y. P. Wang, and J. M. Chang. 1987. Heavy metal concentrations in soils of Taiwan. Publication by the Environmental Protection Administration (EPA) of Taiwan, Taipei, Taiwan.

MacDonald, K. B., W. R. Fraser, F. Wang, and G. W. Lelyk. 1995. A geographical framework for assessing soil quality. In: The health of our soils-Toward sustainable agriculture in Canada. D. F. Acton and L. J. Gregorich (eds.). Centre for Land and Biological Resources Research, Research Branch, Agriculture and Agri-Food Canada, Ottawa, Ontario, pp. 19-30.

Mausbach, M. J., and C. A. Seybold. 1998. Assessment of soil quality. In: Soil quality and agricultural sustainability. L. Rattan (ed.). Sleeping Bear Press, Chelsea, pp. 33-43.

Meek, B. D., L. E. Graham, T. J. Donovan, and K. S. Maberry. 1997. Phosphorus availability in a calcareous soil after high loading rates of animal manure. Soil Sci. Soc. Am. J. 43:741-744.

Merbach, W., J. Garz, W. Schiephake, H. Stumpe, and L. Schmidt. 2000. The long-term fertilization experiment in Halle (Saale), GermanyIntroduction and survey. J. Plant Nutr. Soil Sci. 163:629-638.

Miller, W. P., D. C. Martens, L. W. Zelanzy, and E. T. Kornegay. 1986. Forms of solid phase copper in copper-enriched swine manure. J. Environ. Qual. 15:69-72.

Mullins, G. L., D. C. Martens, W. P. Miller, E. T. Kornegay, and D. L. Hallock. 1982. Copper availability, form, and mobility in soils from three annual copper-enriched hog manure applications. J. Environ. Qual. 11:316-320.

Nelson, D. W., and L. E. Summers. 1982. Total carbon, organic carbon and organic matter. In: Methods of soil analysis: Part 2. Chemical and microbiological methods. Page et al. (eds.). Agron.
Monogr. 9. ASA and SSSA Press, Madison, pp. 539-537.

Novozamsky, I., V. J. G. Houba, R. van Eck, and W. van Vark. 1983. A novel digestion technique for multi-element plant analysis. Commun. Soil Sci. Plant Anal. 14:239-248.

Parkin, T. B. 1993. Spatial variability of microbial processes in soil. J. Environ. Qual. 22:409-417.

SAS Institute. 1995. JMP Statistics and Graphics Guide, Version 3. Cary, NC.

Seybold, C. A., R. P. Dick, and F. J. Pierce. 2001. USDA soil quality test kit: Approaches for comparative assessments. Soil Survey Horiz. 42:43-52.

Schlichting, E. 1986. Einfuehrung in die Bodenkunde, 2nd ed. Parey Verlag, Hamburg.

Shen, Q. R., and Z. G. Shen. 2001. Effects of pig manure and wheat straw on growth of mungbean seedlings grown in aluminium toxic soil. Bioresour. Technol. 76:235-240.

Schroeder, D., and W. H. Blum. 1992. Bodenkunde in Stichworten, 4th ed. Hirt, Berlin.

Shuman, L. M., S. Dudka, and K. Das. 2001. Zinc forms and plant availability in a compost amended soil. Water Air Soil Pollut. 128:1-11.

Sojka, R. E., and D. R. Upchurch. 1999. Reservations regarding the soil quality concept. Soil Sci. Soc. Am. J. 63:1039-1054.

Sparling, G. P. 1997. Soil microbial biomass, activity, and nutrient cycling as indicators of soil health. In: Biological indicators of soil health. C. E. Pankhurst, B.M. Doube and V.V.S.R. Gupta (eds.). CAB International, Wallingford, UK, pp. 97-119.

Spedding, T. A., C. Hamel, G. R. Mehuys, and C. A. Madramootoo. 2004. Soil microbial dynamics in maize-growing soil under different tillage and residue management systems. Soil Biol. Biochem. 36:499-512.

Studdert, G. A., H. E. Echeverria, and E. M. Casanovas. 1997. Crop-pasture rotation for sustaining the quality and productivity of a Typic Argiudoll. Soil Sci. Soc. Am. J. 61:1466-1472.

Tisdale, S. L., W. L. Nelson, and J. D. Beaton. 1985. Soil fertility and fertilizers, 4th ed. Macmillan Publ. Co., New York.

Tisdall, J. M., and J. M. Oades. 1982. Organic matter and water-stable aggregates in soils. J. Soil Sci. 33:141-163.

Waring, S. A., and J. M. Bremner. 1964. Ammonium production in soil under waterlogged conditions as an index of nitrogen availability. Nature. 201: 951-952.

Whalen, K. J., Q. Hu, and A. Liu. 2003. Compost applications increase water-stable aggregates in conventional and no-tillage systems. Soil Sci. Soc. Am. J. 67:1842-1847. 